\title{
Vitamin D levels in actinic keratosis: a preliminary study ${ }^{*}$
}

\author{
Aslı Aksu Çerman¹, Ezgi Aktaş Karabay², Ilknur Kivanc Altunay ${ }^{1}$, Seher Küçükoğlu Cesur ${ }^{3}$
}

DOI: http:/ /dx.doi.org/10.1590/abd1806-4841.20186999

\begin{abstract}
BACKGROUND: Recent studies that investigated the effect of vitamin D on skin cancer risk have exhibited inconsistent results.

OвJECTIVE: The aim of the study was to evaluate vitamin D status in patients with actinic keratosis.

Methods: A cross-sectional study was conducted on 31 patients with actinic keratosis and 29 healthy controls. Serum vitamin D levels in the study group were determined by liquid chromatography/tandem mass spectrometry.

RESULTS: Serum 25(OH)D levels in patients with actinic keratosis were significantly higher than those of the healthy controls $(\mathrm{P}=0.04)$. Prevalence of $25(\mathrm{OH}) \mathrm{D}$ deficiency was significantly higher in the healthy controls $(75.9 \%)$ compared to the patients with actinic keratosis $(54.8 \%)$, but the difference was not statistically significant $(P=0.09)$.

STUDY LimitATIONS: The cross-sectional design of the study, data on smoking based on patient self-report, and subjects' different dietary habits, which can influence $25(\mathrm{OH}) \mathrm{D}$ levels, are the study's limitations.

CONCLUSION: Serum vitamin D level can be used as a marker for ultraviolet B radiation from sun exposure; therefore, it can be used in individuals at risk of actinic keratosis. Oral intake of vitamin D through diet or supplements is proposed instead of prolonged ultraviolet exposure to maintain adequate vitamin D serum levels. Further research is needed to elucidate the role of vitamin D in skin carcinogenesis.
\end{abstract}

Keywords: Keratosis, actinic; Skin neoplasms; Vitamin D

\section{INTRODUCTION}

The main source of vitamin $\mathrm{D}$ is endogenous synthesis in the skin, induced by ultraviolet $\mathrm{B}$ (UVB) radiation. ${ }^{1-4}$ The main circulating form of vitamin D, 25-hydroxyvitamin D [25(OH)D], has a half-life of approximately 2 weeks and is a better reflection of all sources of vitamin D exposure and status than $1,25(\mathrm{OH})_{2} \mathrm{D}_{3}[4]$.The same spectrum of UV radiation $(280-320 \mathrm{~nm})$ is the main cause of skin cancer, but at the same time it is required for vitamin D synthesis in the skin. ${ }^{5-8}$ Studies in the literature have shown different results, with some reporting an association between lower vitamin $\mathrm{D}$ levels and others reporting higher vitamin D levels and increased skin cancer risk. ${ }^{5,9-11}$

Actinic keratosis (AK), also known as solar keratosis, is a pre-cancerous epidermal lesion caused by long-term exposure to
UV radiation, which may progress to squamous cell carcinoma (SCC). In humans, vitamin D receptor (VDR) polymorphisms are associated with the increased development of solar keratoses. ${ }^{12} \mathrm{An}$ other study reported that VDR knockout mice developed numerous non-melanoma skin cancers (NMSCs). ${ }^{13,14}$

The aim of this study was to evaluate vitamin D status in patients with AK.

\section{METHODS}

\section{Patients and controls}

This cross-sectional study included 31 patients with AK and 29 healthy controls, all with a normal body mass index (BMI; $\left.18-25 \mathrm{~kg} / \mathrm{m}^{2}\right)$, as it has been shown that vitamin D deficiency is asso-

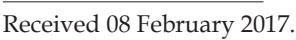

Accepted 23 June 2017.

* Work conducted at the Dermatology and Venereology Department, Şişli Hamidiye Etfal Training and Research Hospital, Istanbul, Turkey. Financial support: None. Conflict of interest: None.

Department of Dermatology and Venereology, Şişli Hamidiye Etfal Training and Research Hospital, Health Science University, Istanbul, Turkey. Department of Dermatology and Venereology, Faculty of Medicine, Bahçeşehir University, Istanbul, Turkey.

Department of Dermatology and Venereology, Medicalpark Bahçelievler Hospital, Istanbul, Turkey.
}

MAILING AdDRESS:

Ezgi Aktaş Karabay

E-mail:ezgiaktasmd@gmail.com 
ciated with obesity. ${ }^{15}$ All individuals were studied during the same period (21 November 2014 to 21 March 2015) to avoid seasonal variations in vitamin $\mathrm{D}$ levels and were selected from the metropolitan area of Istanbul, Turkey. All participants were white-skinned. Sun exposure was similar between patients and controls.

Patients with a history of systemic treatment (e.g. corticosteroids, immunosuppressive therapy, vitamin D or calcium supplementation, cholesterol-lowering drugs) or phototherapy within 6 months of the study were excluded. Subjects with a history of diabetes mellitus, parathyroid or thyroid disorders, autoimmune diseases, anemia, atopy, chronic renal or liver disease, malignancy, plus currently pregnant or lactating females, smokers, and subjects applying sunscreen were also excluded. Data on smoking relied on self-reports. Informed consent was obtained from all individual participants included in the study. The study was approved by the Şişli Hamidiye Etfal Training and Research Hospital Ethics Committee (approval no: 409, date: 23/12/2014) and was conducted according to the Declaration of Helsinki principles.

\section{Serum vitamin $\mathrm{D}$ analysis}

The serum concentration of $25(\mathrm{OH}) \mathrm{D}$ was determined for each participant on the day of enrolment by using liquid chromatography/tandem mass spectrometry (Quattro Premier XE; Waters Corporation, Milford, MA, USA). Serum 25(OH)D concentrations $\leq 20 \mathrm{ng} / \mathrm{mL}$ were defined as deficient. ${ }^{16}$

\section{Statistical analyses}

Statistical analyses were carried out using the Statistical Package for Social Sciences (SPSS) version 15 (IBM, Armonk, NY, U.S.A.). The Mann-Whitney U test was used for the statistical analysis, and the results were expressed as mean \pm standard deviation (SD). Correlations were performed by Spearman's correlation analysis. $\mathrm{P}<0.05$ was considered significant.

\section{RESULTS}

Gender ratio, age, and BMI did not differ significantly between patients with AK ( 25 women, 6 men; mean \pm SD age $70.90 \pm$ 8.97 years; BMI $22.38 \pm 1.63$ ) and healthy controls ( 21 women, 8 men; mean \pm SD age $71.90 \pm 7.18$; BMI $22.37 \pm 1.68)(P=0.46, P=0.83, P=$ 0.76 , respectively) (Table 1$)$.

\section{Serum 25(OH)D levels}

The mean \pm SD serum $25(\mathrm{OH}) \mathrm{D}$ concentration of patients with AK $(19.52 \pm 6.60 \mathrm{ng} / \mathrm{mL})$ was significantly higher than that of healthy controls $(16.03 \pm 7.49 \mathrm{ng} / \mathrm{mL})(P=0.04)$. A $25(\mathrm{OH}) \mathrm{D}$ deficiency $(\leq 20 \mathrm{ng} / \mathrm{mL})$ was observed in $54.8 \%$ of the patients with AK and $75.9 \%$ of healthy controls, but the difference was not statistically significant $(P=0.09)$ (Table 1$)$.

No correlation between the number of lesions and serum $25(\mathrm{OH}) \mathrm{D}$ levels was found in the AK patients $(P=0.14 ; r=0.268)$. When female and male proportions in the study groups were investigated, $25(\mathrm{OH}) \mathrm{D}$ levels were not found to be statistically more significant in female AK patients than in male AK patients (mean \pm $\mathrm{SD} n g / \mathrm{mL} ; 19.82 \pm 11.88$ vs $19.45 \pm 6.60 ; P=0.38)$. Also, there was no significant correlation between age and $25(\mathrm{OH}) \mathrm{D}$ levels in AK patients and controls $(P=0.09, P=0.87$, respectively).

\section{DISCUSSION}

UV radiation promotes skin cancer development by inducing photodamage in human keratinocytes through the formation of cyclobutane pyrimidine dimers (CPD), local immunosuppression, and the oxidative stress mechanism. ${ }^{17-21}$ Vitamin D may have a protective effect against $\mathrm{UV}$ radiation in vitro by reducing $\mathrm{CPD}$, improving CPD repair, reducing UVB-induced apoptosis, and inducing the antioxidant metallothionein. ${ }^{6,22-24}$ But the photoprotective effect of vitamin D on keratinocytes may be dose-dependent. ${ }^{21,23,24}$

Non-melanoma skin cancers include AKs, Bowen's disease, SCC, and basal cell carcinoma (BCC). The role of vitamin D in skin cancer is more complex than in other cancers. UV radiation is the main source of cutaneous vitamin D production and is the main etiologic factor for NMSC. This dilemma has led to inconsistent findings in the literature regarding the amount of sun exposure and vitamin D supplementation for skin cancer prevention. ${ }^{25}$ Furthermore, vitamin D levels in patients with NMSC have shown contradictory results. A recent study by Liang et al. ${ }^{26}$ found elevated $25(\mathrm{OH}) \mathrm{D}$ levels to be associated with increased BCC and SCC incidences. Van der Pols et al. ${ }^{27}$ evaluated the association between serum 25(OH)D levels and skin cancer risk in 1,191 adults. In subjects with a history of skin cancer, $25(\mathrm{OH}) \mathrm{D}$ levels above $75 \mathrm{nmol} / \mathrm{L}$ were associated with a reduced incidence of SCC and with an increased incidence of BCC and melanoma. Eide et $_{\text {al. }}{ }^{8}$ showed that a serum $25(\mathrm{OH}) \mathrm{D}$ level of $15 \mathrm{ng} / \mathrm{mL}$ or higher was associated with an increased NMSC risk in

\begin{tabular}{|c|c|c|c|}
\hline & Actinic keratoses $(n=31)$ & Healthy controls $(n=29)$ & $\mathbf{p}$ \\
\hline Age (mean $\pm \mathrm{SD})$ & $70.90 \pm 8.97$ & $71.90 \pm 7.18$ & $* 0.83$ \\
\hline \multicolumn{4}{|l|}{ Sex, $\mathrm{n}(\%)$} \\
\hline Male & $6(19.35)$ & $8(27.59)$ & \multirow[t]{2}{*}{+0.46} \\
\hline Female & $25(80.65)$ & $21(72.41)$ & \\
\hline $\mathrm{BMI}\left(\mathrm{kg} / \mathrm{m}^{2}\right)($ mean $\pm \mathrm{SD})$ & $22.38 \pm 1.63$ & $25(80.65)$ & $* 0.76$ \\
\hline Serum $25(\mathrm{OH}) \mathrm{D}(\mathrm{ng} / \mathrm{mL}$; mean $\pm \mathrm{SD})$ & $19.52 \pm 6.60$ & $16.03 \pm 7.49$ & \multirow{2}{*}{$* 0.04$} \\
\hline Median (min-max) & $19.7(10.5-42.4)$ & $14.6(3.5-31)$ & \\
\hline Vitamin D deficiency $(\leq 20 \mathrm{ng} / \mathrm{mL}), \mathrm{n}(\%)$ & $17(54.8)$ & $22(75.9)$ & $* 0.09$ \\
\hline
\end{tabular}


3,223 white-skinned patients enrolled in a health maintenance organization, but this was not statistically significant. In addition, a large prospective cohort study reported that elevated plasma $25(\mathrm{OH}) \mathrm{D}$ levels were associated with an increased risk of NMSC and melanoma in the general population. ${ }^{28}$ Tang et al. ${ }^{10}$ revealed that baseline $25(\mathrm{OH}) \mathrm{D}$ levels $>75 \mathrm{nmol} / \mathrm{L}$ were associated with a decreased risk of NMSC in elderly men.

In our study, mean serum vitamin $\mathrm{D}$ in patients with AK $(19.52 \pm 6.60 \mathrm{ng} / \mathrm{mL})$ was higher than in healthy controls $(16.03 \pm$ $7.49 \mathrm{ng} / \mathrm{mL})$. We are of the opinion that plasma $25(\mathrm{OH}) \mathrm{D}$ can be used as a marker for UVB radiation from sun exposure; therefore, it can be used to identify persons at risk of $\mathrm{AK}$, as previously indicated by Afzal et al. ${ }^{28}$

In the literature, vitamin $\mathrm{D}$ deficiency has been reported to be very common in the elderly population. A recent Indian study revealed that $91.2 \%$ of the population over 50 years of age had vitamin D deficiency. ${ }^{29}$ In a study from the Robert Koch Institute, vitamin D deficiency was evident in $75 \%$ of elderly women between 65 and 79 years of age. ${ }^{30} \mathrm{AK}$ is more prevalent in the elderly population. The fact that our population consisted mainly of elderly people may explain the lower than expected levels in the whole cohort.
To our knowledge, this is the first study to compare vitamin D levels in AK patients with healthy controls. However, there are several limitations in our study. It had a cross-sectional design, data on smoking relied on patient self-reporting, and variations in patients' dietary habits may have influenced the levels of 25(OH)D. In addition, the study population was very small, and the findings should be viewed as preliminary.

\section{CONCLUSION}

In conclusion, we think that vitamin D can serve as a marker of chronic sun exposure; therefore, it may correlate with higher incidence of AK, although it does not increase the risk itself. In contrast, vitamin D provides well-established benefits, including protection against several cancers and fracture risk in the elderly. Therefore, regarding the recent studies showing that sun protective measures have not been found to contribute to vitamin D deficiency or insufficiency, we support the use of sun protection, see UV radiation as the main risk factor for $\mathrm{AK}$, and recommend that an adequate amount of vitamin D should be obtained from vitamin D-enriched foods and/or from vitamin D supplements. ${ }^{31-33}$

\section{REFERENCES}

1. LoPiccolo MC, Lim HW. Vitamin D in health and disease. Photodermatol Photoimmunol Photomed. 2010;26:224-9.

2. Mostafa WZ, Hegazy RA. Vitamin D and skin: focus on a complex relationship: a review. J Adv Res. 2015;6:793-804.

3. Saleh HM, Abdel Fattah NS, Hamza HT. Evaluation of serum 25-hydroxyvitamin $\mathrm{D}$ in vitiligo patients with and without autoimmune disease. Photodermatol Photoimmunol Photomed. 2013;29:34-40.

4. Holick MF. Sunlight and vitamin D for bone health and prevention of autoimmune diseases, cancers, and cardiovascular disease. Am J Clin Nutr. 2004;80:1678S-88S.

5. Asgari MM, Tang J, Warton ME, Chren MM, Quesenberry CP Jr, Bikle D, et al. Association of prediagnostic serum vitamin $\mathrm{D}$ levels with the development of basal cell carcinoma. J Invest Dermatol. 2010;130:1438-43.

6. Tang JY, Fu T, Lau C, Oh DH, Bikle DD, Asgari MM.. Vitamin D in cutaneous carcinogenesis. Part II. J Am Acad Dermatol. 2012;67:817.e1-11.

7. Bikle DD, Oda Y, Xie Z. Vitamin D and skin cancer: a problem in gene regulation. $J$ Steroid Biochem Mol Biol. 2005;97:83-91.

8. Nemazannikova N, Antonas K, Dass CR. Role of vitamin D metabolism in cutaneous tumour formation and progression. J Pharm Pharmacol. 2013;65:210.

9. Eide MJ, Johnson DA, Jacobsen GR, Krajenta RJ, Rao DS, Lim HW, et al. Vitamin $\mathrm{D}$ and nonmelanoma skin cancer in a health maintenance organization cohort. Arch Dermatol. 2011;147:1379-84.

10. Tang JY, Parimi N, Wu A, Boscardin WJ, Shikany JM, Chren MM, et al. Osteoporotic Fractures in Men (MrOS) Study Group: Inverse association between serum 25(OH) vitamin D levels and non-melanoma skin cancer in elderly men. Cancer Causes Control. 2010;21:387-91.

11. Tang JY, Fu T, Leblanc E, Manson JE, Feldman D, Linos E, et al. Calcium plus vitamin $D$ supplementation and the risk of nonmelanoma and melanoma skin cancer: post hoc analyses of the women's health initiative randomized controlled trial. J Clin Oncol. 2011;29:3078-84.

12. Carless MA, Kraska T, Lintell N, Neale RE, Green AC, Griffiths LR. Polymorphisms of the VDR gene are associated with presence of solar keratoses on the skin. $\mathrm{Br} \mathrm{J}$ Dermatol. 2008;159:804-10.
13. Zinser GM, Sundberg JP, Welsh J. Vitamin D (3) receptor ablation sensitizes skin to chemically induced tumorigenesis. Carcinogenesis. 2002;23:2103-9.

14. Tang JY, Fu T, Lau C, Oh DH, Bikle DD, Asgari MM. Vitamin D in cutaneous carcinogenesis. Part I. J Am Acad Dermatol. 2012;67:803.e1-12.

15. Vanlint S. Vitamin D and obesity. Nutrients. 2013;5:949-56.

16. Hollis BW, Wagner CL. Normal serum vitamin D levels. N Engl J Med. 2005;352:515-6

17. Reichrath J, Reichrath S. The relevance of the vitamin D endocrine system (VDES) for tumorigenesis, prevention, and treatment of non-melanoma skin cancer (NMSC). Present concepts and future perspectives. Dermatoendocrinol. 2013;5:38-50.

18. Ikehata H, Kawai K, Komura J, Sakatsume K, Wang L, Imai M, et al. UVA1 genotoxicity is mediated not by oxidative damage but by cyclobutane pyrimidine dimers in normal mouse skin. J Invest Dermatol. 2008;128:2289-96.

19. Reddy KK, Gilchrest BA. latrogenic effects of photoprotection recommendations on skin cancer development, vitamin D levels, and general health. Clin Dermatol. 2011;29:644-51.

20. Grossman D, Leffell DJ. The molecular basis of nonmelanoma skin cancer: new understanding. Arch Dermatol. 1997;133(:1263-70.

21. De Haes P, Garmyn M, Degreef $H$, Vantieghem $K$, Bouillon $R$, Segaert $S$ 1,25-dihydroxyvitamin D3 inhibits ultraviolet B-induced apoptosis, Jun kinase activation, and interleukin- 6 production in primary human keratinocytes. J Cell Biochem. 2003;89:663-73

22. Dixon KM, Deo SS, Wong G, Slater M, Norman AW, Bishop JE, et al. Skin cance prevention: a possible role of 1,25dihydroxyvitamin D3 and its analogs. J Steroid Biochem Mol Biol. 2005;97:137-43.

23. Hanada K, Sawamura D, Nakano H, Hashimoto I. Possible role of 1,25-dihydroxyvitamin D3-induced metallothionein in photoprotection against UVB injury in mouse skin and cultured rat keratinocytes. J Dermatol Sci. 1995;9:203-8.

24. Lee J, Youn Jl. The photoprotective effect of 1,25-dihydroxyvitamin D3 on ultraviolet light B-induced damage in keratinocyte and its mechanism of action. J Dermatol Sci. 1998;18:11-8.

25. Burns EM, Elmets CA, Yusuf N. Vitamin D and skin cancer. Photochem Photobiol. 2015;91:201-9. 
26. Liang G, Nan H, Qureshi AA, Han J. Pre-diagnostic plasma 25-hydroxyvitamin D levels and risk of non-melanoma skin cancer in women. PLoS One. 2012;7:e35211.

27. van der Pols JC, Russell A, Bauer U, Neale RE, Kimlin MG, Green AC. Vitamin D status and skin cancer risk independent of time outdoors: 11-year prospective study in an Australian community. J Invest Dermatol. 2013;133:637-641.

28. Afzal S, Nordestgaard BG, Bojesen SE. Plasma 25-hydroxyvitamin D and risk of non-melanoma and melanoma skin cancer: a prospective cohort study. J Invest Dermatol. 2013;133:629-36.

29. Marwaha RK, Tandon N, Garg MK, Kanwar R, Narang A, Sastry A, et al. Vitamin D status in healthy Indians aged 50 years and above. J Assoc Physicians India. 2011;59:706-9.
30. Hintzpeter B, Mensink GB, Thierfelder W, Müller MJ, Scheidt-Nave C. Vitamin D status and health correlates among German adults. Eur J Clin Nutr. 2008;62:1079-89.

31. Norval M, Wulf HC. Does chronic sunscreen use reduce vitamin D production to insufficient levels? Br J Dermatol. 2009;161:732-6.

32. Marks R, Foley PA, Jolley D, Knight KR, Harrison J, Thompson SC. The effect of regular sunscreen use on vitamin D levels in an Australian population; result of a randomized controlled trial. Arch Dermatol. 1995;131:415-21.

33. Jayaratne N, Russell A, van der Pols JC. Sun protection and vitamin D status in an Australian subtropical community. Prev Med. 2012;55:146-50.

\section{AUTHORS CONTRIBUTION}

Aslı Aksu Çerman

(iD) ORCID 0000-0003-3979-7486

Statistical analysis; Approval of the final version of the manuscript; Conception and planning if the study; Elaboration and writing of the manuscript; Intellectual participation in propaedeutic and/or therapeutic conduct of cases studied; Critical review of the literature

Ezgi Aktaş Karabay

(iD) ORCID 0000-0001-6634-2810

Approval of the final version of the manuscript; Conception and planning if the study; Obtaining, analyzing and interpreting the data; Effective participation in research orientation; Intellectual participation in propaedeutic and/or therapeutic conduct of cases studied; Critical review of the literature
Ilknur Kivanc Altunay $\quad$ (iD) ORCID 0000-0002-1354-7123

Approval of the final version of the manuscript; Critical review of the manuscript Seher Küçükoğlu Cesur iD ORCID 0000-0001-5713-9941

Approval of the final version of the manuscript; Critical review of the manuscript

How to cite this article: Aksu Çerman A, Aktaş Karabay E, Altunay IK, Küçükoğlu Cesur S. Vitamin D levels in actinic keratosis: a preliminary study. An Bras Dermatol. 2018;93(4):535-8. 